\title{
PERBEDAAN PENGARUH PEMBERIAN ANGKAK DALAM PEMBUATAN SOSIS AYAM TERHADAP SIFAT FISIK DAN ORLAB
}

\author{
Sudjatinah $^{1}$ dan C. Hari Wibowo ${ }^{2}$ \\ ${ }^{\mathbf{1 , 2}}$ Fakultas Teknologi Pertanian Jurusan Teknologi Hasil Pertanian Universitas Semarang
}

\begin{abstract}
Abstraksi
Sosis daging ayam adalah bahan pangan yang berasal dari potongan kecil daging ayam yang digiling dan diberi bumbu. Bahan sosis yang digunakan adalah daging ayam, karena daging merupakan white meat jadi terlihat pucat jika diolah menjadi sosis berbeda dengan sosis daging sapi, oleh karena itu dilakukan penambahan pewarna alami yang aman dikonsumsi yaitu angkak. Tujuan dari penelitian ini adalah untuk mengetahui perbedaan pengaruh konsentrasi angkak sebagai pewarna alami terhadap sifat fisik dan orlab sosis daging ayam.

Metode yang digunakan dalam penelitian ini adalah metode experimental laboratories. Faktor perlakuan yang diterapkan adalah tanpa penambahan angkak $(0 \%)$ dan penambahan angkak 1,5\%. Variabel yang diamati yaitu sifat fisik (kadar air, cooking loss), kekenyalan dan orlab. Data yang diperoleh dianalisis menggunakan $t$ test. Hasil penelitian yang telah dilakukan menunjukkan bahwa perlakuan penambahan angkak dengan konsentrasi yang berbeda dalam pembuatan sosis daging ayam afkir (sebagai pewarna alami) berpengaruh nyata $(\mathrm{p}<0,05)$ terhadap rata-rata cooking loss tetapi tidak berbeda pada rata-rata kadar air dan kekenyalan. Penambahan angkak dengan konsentrasi $1,5 \%$ pada pengolahan sosis daging ayam (sebagai pewarna alami) menghasilkan karakteristik mutu sosis daging ayam yang lebih baik dengan syarat mutu sosis daging ayam dibandingkan tanpa penambahan angkak.
\end{abstract}

Keyword : Sosis Ayam, experimental laboratories, Angkak

\section{A. PENDAHULUAN}

Daging merupakan salah satu produk ternak yang menjadi penyuplai protein hewani terbesar di Indonesia. Indonesia kaya akan kebudayaan menyebabkan jenis olahan daging tersebut berbeda antara satu daerah dengan daerah lainnya. Pada umumnya masyarakat Indonesia menghendaki daging yang empuk yang berasal dari ternak yang memiliki umur potong yang muda, selain itu beberapa jenis olahan makanan dari daging juga mempertimbangkan serat daging, tingkat kekenyalan dan kandungan air dari daging tersebut. Hal ini terkait dengan cara pengolahannya dari berbagai olahan makanan tersebut seperti perebusan, penggilingan, pembakaran dan penggorengan.

Ayam petelur afkir merupakan ayam petelur yang sudah tidak produktif pada akhir masa produksi telur, yaitu pada usia 72 hingga 80 minggu (Murtidjo, 2003). Salah satu penyebab dari kurangnya pemanfaatan ayam petelur afkir adalah dagingnya sangat liat, sehingga kurang diterima oleh sebagian konsumen. Hal ini dapat diatasi dengan mengolah daging ayam petelur afkir menjadi produk restructured meat, karena terdapat bahan lain yang ditambahkan untuk meningkatkan palatabilitas. Salah satu cara untuk memanfaatkan daging ayam petelur afkir adalah dengan mengolahnya menjadi sosis daging ayam.

Sosis adalah bahan pangan yang berasal dari potongan kecil daging yang digiling dan diberi bumbu, dapat langsung disiapkan dan segera dimasak untuk dimakan. Sosis atau sausage berasal dari kata salsus yang berarti menggiling dengan garam. Sosis merupakan produk pengolahan pangan. Daging digiling dan dihaluskan, dicampur bumbu-bumbu kemudian diaduk hingga tercampur rata dan dimasukan ke dalam selongsong (Winarno, 1990). Sosis merupakan produk pengolahan daging yang mempunyai nilai gizi tinggi. Komposisi gizi sosis berbeda-beda, tegantung pada jenis daging yang digunakan dalam pengolahannya (Winarno, 1992). Sosis berdasarkan tingkat kehalusannya penggilingan daging dibedakan atas sosis digiling dan emulsi. Pada sosis daging giling, daging tidak dihaluskan sehingga masih terlihat serat-serat daging yang belum hancur dan menghasilkan tekstur khas. Sedangkan dalam sosis emulsi daging digiling halus sampai terbentuk emulsi lemak yang ditambahkan (Wottom, 1987).

Produk sosis adalah produk yang dibuat dengan campuran berbagai bahan dengan bahan baku utama adalah daging. Ada berbagai jenis sosis di pasaran, serta resep yang dibuat, akan tetapi secara umum resep pembuatannya terdiri dari daging, bahan pengikat (binder), bahan pengisi (filler), emulsi, bumbu dan selongsong yang harus disediakan (Pearson, 1987). Dalam proses pembuatan selanjutnya, pada sosis ditambahkan bahan pengikat ataupun bahan pengisi yang berfungsi untuk menarik air, memberi warna khas, membentuk tekstur yang padat, memperbaiki emulsi, menurunkan penyusutan waktu pemasakan, memperbaiki cita rasa dan sifat irisan. Bahan pengikat dan pengisi dibedakan berdasarkan kadar proteinnya. Bahan pengikat mengandung protein yang lebih tinggi, sedangkan bahan pengisi mengandung bahan karbohidrat saja. Bahan pengikat pada umumnya berupa susu skim, alginat, karagenan, gelatin, dan sejenisnya. Sedangkan bahan pengisi berupa tepung 
terigu, tepung beras, tepung tapioka,tepung roti, dan tepung kentang. Selain itu, juga ditambahkan garam, air rempah, gula nitrit atau sendawa. Penambahan gula dapat membantu mempertahankan aroma dan, mengurangi efek pengerasan dari garam glukosa, jumlah penambahan sekitar $1 \%$. Penambahan nitrit atau sendawa sebagai pewarna khas curing, yaitu pewarna merah yang stabil. Karena daging ayam merupakan white meat jadi terlihat pucat jika diolah menjadi sosis berbeda dengan sosis daging sapi. Penambahan nitrit ini dibatasi maksimum 200ppm (200mg per kg bahan), karena pada konsentrasi tinggi dapat membahayakan kesehatan. Pewarna alami aman digunakan dalam bahan pangan serta tidak menimbulkan gangguan kesehatan. Salah satu pewarna alami yang digunakan di Asia untuk memberikan warna merah yang menarik yaitu angkak (Atma, 2015).

Penambahan angkak dalam pembuatan sosis ayam berperan sebagai pemberi pigmen merah, sebagai pengganti nitrit. Angkak merupakan alternatif yang cukup baik, karena angkak juga mampu berperan sebagai pengawet daging. Karena angkak juga bersifat antimikrobial serta sebagai pembangkit rasa (flavouring enhancher).

Angkak merupakan pengawet dan pewarna alami dan menyehatkan. Warna merah angkak sangat potensial sebagai pengganti warna merah sintetis, yang saat ini penggunaannya sangat luas pada berbagai produk makanan. Sebagai pewarna alami, angkak memiliki sifat yang cukup stabil, dapat bercampur dengan pigmen warna lain, serta tidak beracun. Pigmen warna utama yang dihasilkan oleh Monascus purpureus pada fermentasi angkak adalah monaskorubrin dan monaskoflavin. Kemampuan memberi warna merah yang cukup stabil ini diharapkan bisa menggantikan bahan pewarna kimiawi/sintetis ataupun menggantikan penggunaan sodium nitrit. Penggunaan sodium nitrit banyak digunakan pada produk olahan daging (sosis dan kornet) karena mampu memberikan warna merah yang relatif stabil akibat terbentuknya senyawa nitrosomiglobim (Soeparno, 1993). Akan tetapi dampak penggunaan nitrit yang berlebihan adalah kekhawatiran timbulnya efek karsiogenik. Oleh karena itu alternatif untuk mengurangi resiko yang tidak diinginkan adalah penggunaan angkak.

\section{B. Metodologi}

\subsection{Waktu dan Tempat Pelaksanaan}

Penelitian ini berlangsung di Laboraturium Rekayasa pangan Teknologi Pertanian Universitas Semarang. Pembuatan sosis ayam dilakukan di Laboraturium Rekayasa pangan Teknologi Pertanian Universitas Semarang, pengujian (Kimia) dilakukan di Laboratorium Kimia dan Biokimia Universitas Semarang.

\subsection{Bahan dan Alat}

1. Bahan

Bahan yang digunakan untuk pembuatan sosis ayam ini antara lain : daging ayam, Angkak ,minyak nabati, es, air es, tepung tapioka, susu skim, STPP, garam, bawang putih, merica, dan jahe.

a). Bahan uji kadar protein :

1). Detruksi (2gram sosis, 2 tablet kjeldahl, 3 butir batu didih, $15 \mathrm{ml} \mathrm{H}_{2} \mathrm{SO}_{4}$ ).

2). Destilasi (100ml aquadest, $60 \mathrm{ml} \mathrm{NaOH}$ 40\%, $25 \mathrm{ml} \mathrm{H} 3 \mathrm{BO} 4$, methyl red).

3). Titrasi $(\mathrm{HCl} 0,2 \mathrm{~N})$

b). Bahan uji kadar lemak :

Sampel sosis daging ayam, N-Hexana

2. Alat

Alat yang digunakan untuk penelitian ini antara lain : selonsong sosis, kompor gas, panci, timbangan digital, baskom, sendok, blender, alat penggiling daging (chopper), solet, kertas saring, refrigerator, wadah tertutup, talenan, kain hitam, pisau, label, dan pipping bag.

a). Alat uji kadar protein :

Timbangan analitik, labu kjeldahl, soxhlet, sentrifus, penetrometer, distilasi, erlemeyer, tabung reaksi, rak tabung, pipet tetes, dan pipet skala.

b). Alat uji kadar lemak

Timbangan digital, kertas saring, soxhlet, desikator, labu lemak, oven, gelas ukur, kondensor.

c). Alat Uji Kadar Air

Botol timbang, oven, desikator.

d). Alat Uji Tektur ( Kekenyalan )

Tekstur Analyzer merk LLDYD, tipe 1000S.

\subsection{Prosedur Penelitian}

1. Pembuatan bahan pewarna alami bubuk angkak

Beras merah fermentasi (angkak) digiling menggunakan mixer dengan kecepatan maximum selama 3menit. Selanjutnya dilakukan pengayakan dengan menggunakan ayakan 80mesh, lalu angkak bubuk siap di timbang dan dicampur ke dalam adonan pembuatan sosis daging ayam. Proses pembuatan bubuk angkak dapat dilihat pada Gambar 1.

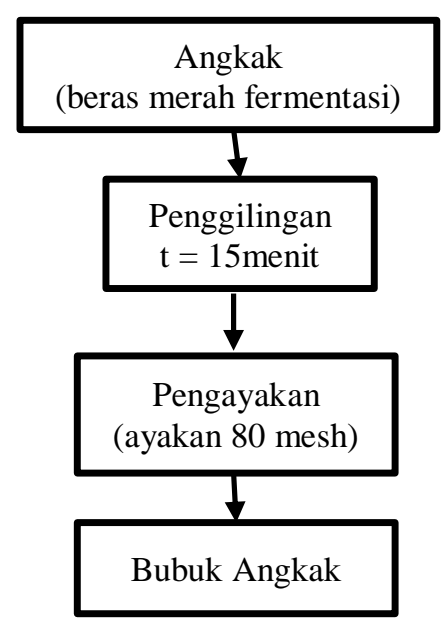

Gambar 1. Diagram alir pembuatan bubuk angkak

2. Pembuatan sosis daging ayam afkir

Fillet ayam (daging ayam tanpa tulang) dipotong - potong dan dicuci. Selanjutnya daging 
dicuci dan digiling dengan alat penggiling daging (chopper). Daging giling dicampur dengan bahan bahan seperti minyak sayur (3\%), garam $(3 \%)$ dan STPP $(0,3 \%)$, tepung tapioka (3\%), susu skim $(5 \%)$, es dan air es (20\%), bumbu - bumbu (2\%), dan penambahan angkak dengan konsentrasi masingmasing $(0 \%, 0,75 \%, 1 \%, 1,25 \%, 1,5 \%)$. Setelah bahan - bahan tercampur sempurna, lalu dimasukkan ke dalam selongsong sintesis, dengan menggunakan plastik dan corong kemudian diikat dengan menggunakan tali. Sosis dimasak dalam air yang mendidih pada suhu sekitar $85-90^{\circ} \mathrm{C}$ selama 45 menit. Setelah selesai pemasakan, dilakukan penirisan lalu sosis didinginkan. Selanjutnya dilakukan uji kadar protein, uji kadar lemak, uji kadar air, dan uji tekstur (kekenyalan). Proses pembuatan sosis dapat dilihat pada Gambar 2.

\subsection{Peubah yang Diamati}

Metode yang digunakan dalam penelitian ini adalah metode experimental laboratories. Faktor perlakuan yang diterapkan adalah tanpa penambahan angkak (0 \%) dan penambahan angkak 1,5\%. Peubah yang diamati yaitu sifat fisik (kadar air, cooking loss), kekenyalan dan orlab. Data yang diperoleh dianalisis menggunakan $t$ test.

1. Kadar air ( Sudarmadji, 1989)

Timbang sampel bahan sebanyak 1-2 gram dalam botol timbang yang telah diketahui beratnya. Kemudian dikeringkan dalam oven pada suhu 100 $105^{\circ} \mathrm{C}$ selama 3-5 jam, tergantung dari bahannya. Kemudian didinginkan dalam desikator selama 5 menit dan ditimbang. Dipanaskan kembali dalam oven selama 30 menit, didinginkan dalam desikator dan ditimbang sampai beratnya konstan (selisish penimbangan berturut-turut kurang dari $0,2 \mathrm{mg}$ ). Pengurangan berat merupakan banyaknya air air dalam bahan atau dapat dituliskan dengan rumus :

$$
\begin{aligned}
& \text { Kadar Air }=\frac{(X+Y)-Z}{Y} .100 \% \\
& \text { Dimana : } \\
& \mathrm{X}=\text { berat botol timbang } \\
& \mathrm{Y}=\text { berat sampel } \\
& \mathrm{Z}=\text { berat botol timbang dan sampel setelah } \\
& \text { dikeringkan }
\end{aligned}
$$

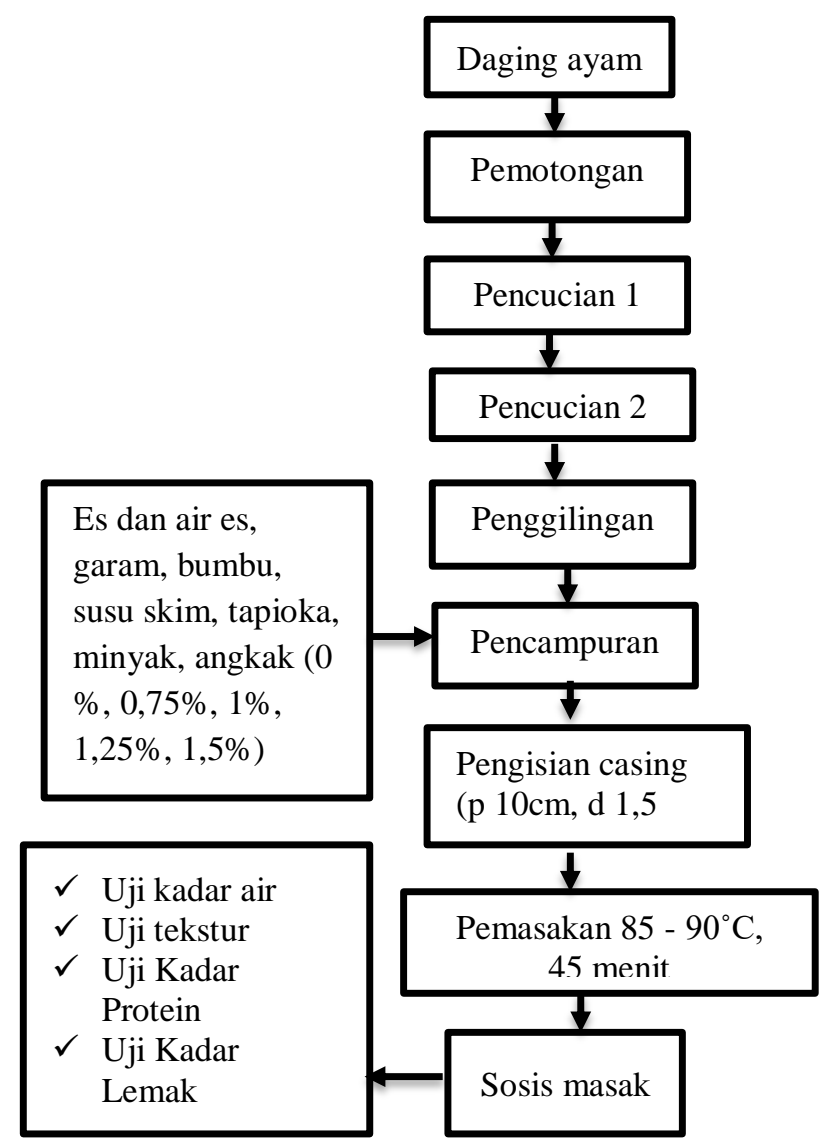

Gambar 2. Diagram alir pembuatan sosis daging ayam.

Perhitungan konsentrasi bubuk angkak

$$
\begin{gathered}
\text { Rumus }(\text { gram })=\text { konsentrasi angkak }(\%) \text { x berat } \\
\text { bahan adonan }(\text { gram }) .
\end{gathered}
$$

\section{Tekstur (kekenyalan)}

Pengujian kekenyalan dapat dilakukan dengan alat Instrument LLDYD Tekstur Analyzer, merk LLDYD, tipe 1000 S, spesifikasi Load Max 5000 N (Extention $\max 1000 \mathrm{~mm}$ ). Prosedur pelaksanaan pengujian kekenyalan adalah kabel data dari Teksture Analyzer dipastikan telah tersambung ke CPU komputer kemudian komputer dinyalakan. Jarum penusuk sampel (proble) dipasang dan diatur posisinya sampai mendekati sampel, kemudian program dari monitor diaplikasikan untuk menjalankan probe. Sebelumnya dipastikan bahwa nilai yang ada pada monitor nol, kemudian pilih menu start test pada monitor sehingga probe akan bergerak sampai menusuk sampel sosis, pengujian selesai apabila probe kembali ke posisi semula. Hasil yang terlihat dalam bentuk grafik dan angka.

1. Cooking Loss

a) Timbang berat sosis sebelum dimasak dengan timbangan digital

b) Setelah itu timbang berat sosis setelah ditimbang

c) Lalu hitung dengan rumus 
Cooking loss

$=\frac{\text { berat sebelum pemasakan }- \text { berat setelah pemasakan }}{\mathrm{X}}$ $100 \%$ bera!sebelum pemasakan

2. Uji organoleptik

Teknik pengujian organoleptik ini menggunakan teknik uji skoring dengan memanfaatkan panelis tidak terlatih sebanyak 20 orang. Pengujian ini berdasarkan penggolongan berdasarkan sifat. Skor yang diperoleh kemudian diuji secara statistik untuk mengetahui apakah terdapat perbedaan atau tidak. Masing-masing sampel Sosis Ayam diuji organoleptik berdasarkan indikator warna, rasa, aroma dan tekstur.

\section{HASIL DAN PEMBAHASAN}

\section{Rata rata Kadar Air}

Rata rata kadar lemak pada masing masing perlakuan P1 dan P2, adalah 67,95 \% dan 67,91\% (Tabel 1). Grafik dapat dilihat pada Gambar 3

Tabel 1. Rata-rata Kadar Air

\begin{tabular}{ccc}
\multicolumn{3}{c}{ Tabel 1. Rata-rata Kadar Air } \\
\hline U1 & P1 & P2 \\
U2 & 68,32 & 68,24 \\
U3 & 68,11 & 68,10 \\
U4 & 67,80 & 67,55 \\
U5 & 67,92 & 67,72 \\
\hline Rata-rata & 67,60 & 67,95 \\
\hline
\end{tabular}

Sumber: Data Primer (2017)

Keterangan: Superskrip dengan huruf kecil yang sama pada baris yang sama menunjukkan tidak berbeda nyata $(\mathrm{p}>0,05)$.

Hasil analisis statistik menunjukkan bahwa tidak terdapat perbedaan antara rata-rata kadar air pada perlakuan P1 dan P2 ( $>00,05)$.

Hasil uji rata-rata kadar air sosis berkisar antara $67,91 \%$ dan $67,95 \%$ sudah memenuhi syarat jika dibandingkan dengan SNI 01-3820-1995 karena kadar air sosis maksimal $67,0 \%$.

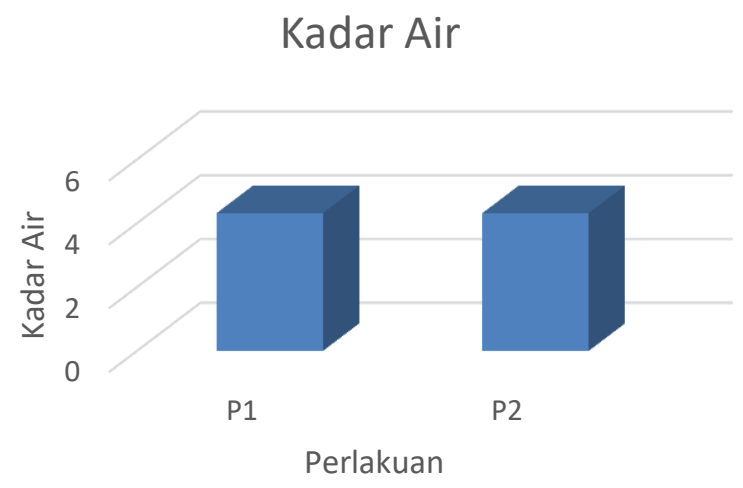

Gambar 3 Grafik rata-rata Kadar Air

Penambahan angkak tidak menunjukkan perbedaan yang nyata $(\mathrm{p}>0,05)$ terhadap kadar air.
Sosis ayam kontrol memiliki kadar air tidak berbeda dibandingkan sosis ayam dengan perlakuan penambahan angkak. Hal ini disebabkan karena kemampuan protein menahan air pada sosis kontrol relatif sama dibandingkan dengan sosis perlakuan. Swatland (2000) menyatakan bahwa kapasitas menahan air (water-holding capasity) adalah kemampuan daging untuk mempertahankan air, sedangkan kapasitas mengikat air (water-binding capasity) adalah kemampuan daging mengikat air yang ditambahkan ke dalam produk. Menurut Kumari et al. (2009), kandungan air pada angkak sangat rendah yaitu hanya $9,90 \%$ sehingga penambahan angkak tidak berpengaruh terhadap kadar air sosis. Hasil penelitian Liu et al. (2010) menunjukkan bahwa penambahan angkak hingga level 1,5\% menghasilkan kadar air yang tidak signifikan.

\section{Rata rata Cooking Loss}

Rata rata kadar cooking loss pada masing masing perlakuan P1 dan P2, adalah 15,19 dan 8,37 (Tabel 2). Grafik dapat dilihat pada Gambar 4

Tabel 2. Rata-rata Cooking Loss

\begin{tabular}{ccc}
\hline & P1 & P2 \\
\hline U1 & 14,88 & 8,33 \\
U2 & 15,10 & 8,38 \\
U3 & 15,18 & 8,42 \\
U4 & 15,01 & 8,35 \\
U5 & 15,81 & 8,35 \\
\hline Rata-rata & $15,19^{\mathrm{a}}$ & $8,37^{\mathrm{b}}$ \\
\hline
\end{tabular}

Sumber: Data Primer (2017)

Keterangan: Superskrip dengan huruf kecil yang berbeda pada baris yang sama menunjukkan berbeda nyata $(\mathrm{p}<0,05)$.

Hasil analisis statistik menunjukkan bahwa terdapat perbedaan antara rata-rata cooking loss pada perlakuan P1 dan P2 ( $<<0,05)$.

Cooking loss sosis berkaitan dengan berkurangnya zat makanan akibat hilang, terurai dan terdegradasi selama pemasakan. Kehilangan zat tersebut akibat larut selama pemasakan menjadi komponen volatil atau terdegradasi menjadi komponen yang lebih sederhana.

\section{Cooking Loss}

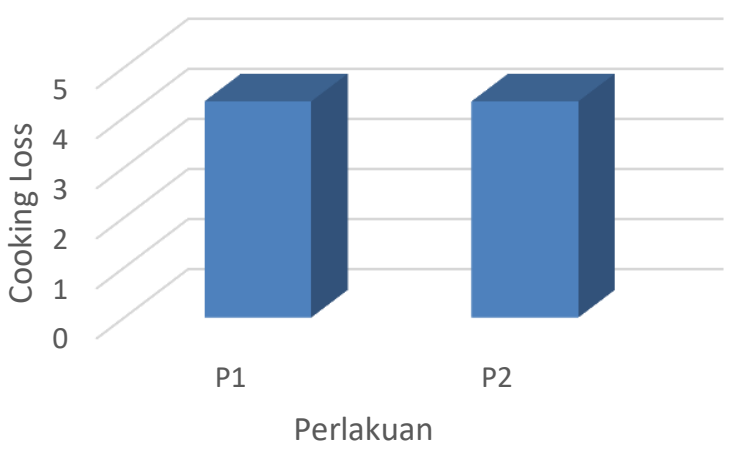

Gambar 4 Grafik rata-rata Cooking Loss 
Berdasarkan gambar 2 menunjukkan tren penurunan grafik cooking loss akibat penambahan angkak. P1 nilai cooking loss lebih tinggi daripada P2. Hal ini diduga pemberian angkak berpengaruh terhadap cooking loss sosis, semakin tinggi pemberian konsentrasi angkak, maka cooking loss semakin berkurang. Beberapa faktor lain yang juga berkaitan dengan susut masak kornet adalah proses pemasakan, air yang ada pada kornet mengalami pengeluaran akibat menurunnya daya ikat air (DIA). Kondisi ini akibat terjadinya denaturasi protein pada saat pemasakan, (Bouton dan Harris, 1972; dalam Soeparno, 1994). Demikian pula pada saat pemasakan, zat-zat makanan yang ada pada kornet mengalami berbagai reaksi dan degradasi, terutama pada zat-zat makanan yang tidak tahan dan kurang stabil akibatnya sebagian zat-zat makanan akan terurai menjadi zat yang lebih sederhana.

\section{Kekenyalan}

Rata rata uji tekstur kekenyalan pada masing masing perlakuan P1 dan P2 adalah 4,32 dan 4,32 (Tabel 3). Grafik dapat dilihat pada Gambar 5

Tabel 3. Rata-rata Uji kekenyalan

\begin{tabular}{ccc}
\hline & $\mathrm{P} 1$ & $\mathrm{P} 2$ \\
\hline $\mathrm{U} 1$ & 4,3 & 4,3 \\
$\mathrm{U} 2$ & 4,4 & 4,2 \\
$\mathrm{U} 3$ & 4,3 & 4,4 \\
U4 & 4,4 & 4,3 \\
U5 & 4,2 & 4,4 \\
\hline Rata-rata & $4,32^{\mathrm{a}}$ & $4,32^{\mathrm{a}}$ \\
\hline
\end{tabular}

Sumber: Data Primer (2017)

Keterangan: Superskrip dengan huruf kecil yang sama pada baris yang sama menunjukkan tidak berbeda nyata $(p>0,05)$.

Hasil analisis statistik menunjukkan bahwa tidak terdapat perbedaan antara rata-rata tekstur kekenyalan pada perlakuan P1 dan P2 ( $>00,05)$. terhadap tekstur sosis. Nilai tekstur sosis ayam semakin kenyal dengan penambahan angkak, hal ini disebabkan karena bahan dasar angkak yang terbuat dari beras yang mengandung pati cukup tinggi dan mempunyai sifat mengikat air. Meskipun menurut Rompis (1998), daya mengikat air yang tinggi menyebabkan sedikit saja air yang hilang selama pemasakan sosis, sehingga menyebabkan tekstur menjadi lebih kenyal. Tetapi dengan adanya bahan yang berfungsi sebagai pengisi sosis seperti tepung tapioka selama proses pengolahan sosis maka sifat mengikat air tersebut sudah dilakukan oleh bahan pengisi. Oleh karena itu kandungan pati sosis yang cukup tinggi atau melebihi batas karena pencampuran dari tepung tapioka dan angkak menyebabkan air yang terserap melebihi kapasitas sehingga teksturnya dapat menjadi lebih empuk. Selain itu, penambahan susu skim juga dapat meningkatkan daya mengikat air, sehingga tekstur sosis ayam menjadi semakin kenyal atau lembek.

\section{SIMPULAN DAN SARAN}

\section{Simpulan}

Berdasarkan hasil penelitian yang telah dilakukan, dapat diambil simpulan sebagai berikut :

a. Perlakuan penambahan angkak dengan konsentrasi yang berbeda dalam pembuatan sosis daging ayam afkir (sebagai pewarna alami) berpengaruh nyata $(\mathrm{p}<0,05)$ terhadap rata-rata cooking loss tetapi tidak berbeda pada rata-rata kadar air dan kekenyalan.

b. Penambahan angkak dengan konsentrasi $1,5 \%$ pada pengolahan sosis daging ayam (sebagai pewarna alami) menghasilkan karakteristik mutu sosis daging ayam yang lebih baik dengan syarat mutu sosis daging ayam dibandingkan tanpa penambahan angkak.

\section{Saran}

Disarankan kepada masyarakat untuk menggunakan angkak dengan level 1,5\% sebagai pewarna sosis alami pengganti nitrit.

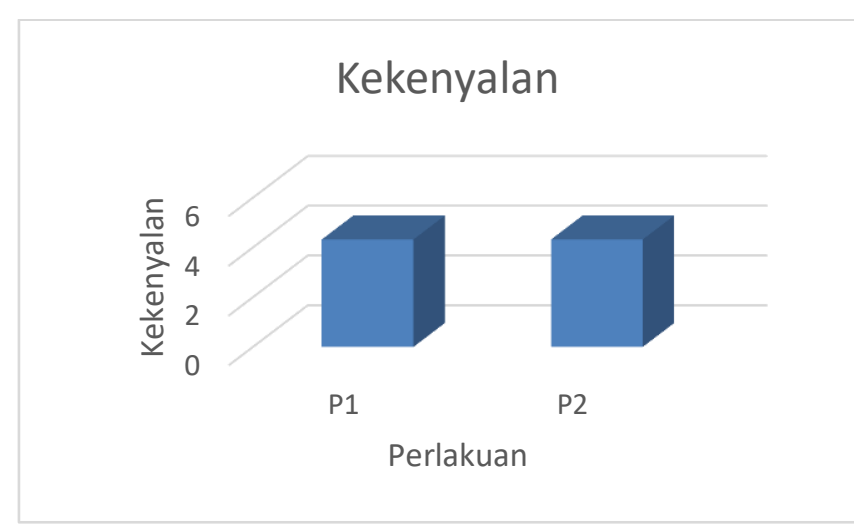

Gambar 5. Kekenyalan

Penambahan angkak dengan berbagai perbedaan konsentrasi tidak memberikan perbedaan yang nyata 


\section{DAFTAR PUSTAKA}

Aberle, E. D., Forrest J. C, Gerral D. E \& Mills E. W. 2001. Principle of Meat Science. Fourth Ed. Kendall/Hunt Publishing Company, America.

Anonim, 2011. Kadar Air Pada Bahan Pangan. http://yogyamerah.

blogspot.com/2011/10/kadar-air-padabahan-pangan.html. Diakses Pada Tanggal 04 Maret 2017, Semarang.

Anonim, 2012. Penetapan Kadar Air Metode Oven Pengering.

http://wulaniriky.wordpress.com/2011/01/19 /penetapankadar-air-Metode-Ovenpengering-an. Diakses Pada Tanggal 04 Maret 2017, Semarang.

Astawan, M. 2009. Departemen Teknologi Pangan Dan Gizi

IPB.http://www.masenchipz.com/bahayalaten-sosis. 05 Juli 2009.

Atma, Yoni . 2015. Studi Penggunaan Angkak Sebagai Pewarna Alami Dalam Pengolahan Sosis Daging Sapi. Skripsi. Universitas Muhammadiyah Jakarta.

Chuaynukool, K. Wattanachant S. and Siripongvutikorn, S. 2007. Chemical and Physical Properties of Raw and Cooked Spent hen, Broiler and Thai Indigenous Chicken Muscles in Mixed Herbs Acidified Soup (Tom Yum). Journal of Food Technology 5: 180-186.

Departemen Kesehatan RI. 1996. Daftar Komposisi Bahan Makanan. Penerbit Bhratara, Jakarta.

Food and Agricultural Organization. 2005. Small-Scale Sausage Production.

http://www.fao.org/docrep/003/x6556502.ht m Diakses pada 2 Februari 2017.

Gadiyaram, K. M. \& G. Kannan. 2004. Comparison of textural properties of low-fat chevon, beef, pork, and mixed-meat sausage. J. Animal Sci. 34 (1) : 212-214.

Gillespie, R. \& F. B. Flanders. 2009. Breeds of Beef Cattle. In: Modern Livestock and Poultry Production. 8th ed. Delmar cengage learning, Clifton Park.

Hadiwiyoto, S.2011. Produk Meat Emulsions.http://foodreview.co.id( 17 Desember 2015).

Heinz G, Hautzinger P. 2007. Meat processing technology for small to medium scale producers. Bangkok: Food Agriculture Organization of the United Nation.

Hidayat, N. dan Elfi Anis Saati. (2006). Membuat Pewarna Alami. Surabaya:Penerbit Trubus Agrisarana. Hal. 35.

Hui, F. H. 1992. Encyclopedia of Food Science and Technology. John Willy and Sons, Inc. USA.

Idris, S. 1984.Pengawetan Telur. Kerjasama Unversitas Brawijaya dengan NUFFIC Belanda.
Kramlich, W. E., A. M. Pearson, dan F. W. Tauber. 1973. Processed Meats. Westport Connecticut, The AVI Publishing Company, Inc.

Kramlich, W. E. 1973. Sausage Product. $2^{\text {nd }}$ Edition. W. H. Freeman and Company, San Fransisco.

Kramlich, W. E., A. M. Pearson dan F. W. Tauber. 1984. Processed Meat, AVI Publishing Co. Inc. Connecticut.

Kumari, H.P. Mohan, K.A. Naidu, S. Vishwanatha, K. Narasimhamurthy dan G. Vijayalakshmi. 2009. Safety evaluation of Monascus purpureus red mould rice inalbino rats. Food and Chemical Toxicology 47: 1739-1746.

Litbang Deptan. 2007. Pengganti Formalin. Asam Asetat Dapat Untuk Mengawetkan Daging Ayam. http://www.litbang.deptan.go.id Diakses pada 2 Februari 2017.

Liu, D.C., S.W. Wu dan F.J. Tan. 2010. Effects pf addition of anka rice on the qualities of lownitrite chinese sausages. Food Chemistry 118: $245-250$.

Moedjiharto, T. J. 2003. Evaluasi fisikokimia sosis tempe-dumbo. Jurnal Teknologi dan Industri Pangan. 16 (2) : 164-168.

Murtidjo, B. A. 2003. Pedoman Beternak Ayam Broiler. Kanisius, Yogyakarta.

Naruki, S. dan Kanoni. 1992. Kimia dan Teknologi Pengolahan Hasil Hewani. PAU Pangan dan Gizi. UGM, Yogyakarta.

Pisula, A. 1984. Meat Processing. Rome Italy: FAO.

Price, J. F. Dan B. S. Schweigert. 1987. The Science of Meat and Meat Products $3^{\text {rd }}$ ed. Wesport Connecticut, The AVI Publishing Company, Inc.

Priyawinatkul, W., K. H. Mc Watters, L. R. Beuchat, and R. D Phillips. 1997. Optimizing Acceptability of Chicken Nuggets Containing Fermented Cowpea and Peanuts Flours, Journal of Food Science 62 (4): 889893.

Rompins, J. E. G. 1998. Pengaruh kombinasi bahan pengikat dan bahan pengisi terhadap sifat fisik kimia serta palatabilitas sosis sapi. Tesis.Program Pascasarjana. Institut Pertanian Bogor, Bogor.

Setyaningsih D, Apriyantono A, dan Sari MP. 2010. Analisis Sensori untuk Industri Pangan dan Agro. IPB Press, Bogor

Soekarto, S. T. 1990. Dasar-Dasar Pengawasan dan Standarisasi Mutu Pangan. IPB Press, Bogor.

Soeparno, 2005. Ilmu dan Teknologi Daging. Gajah Mada University Press. Yogyakarta.

Suhardjo \& C. M. Kusharto. 1992. Prinsip-prinsip Ilmu Gizi. Pusat Antar Universitas. Institut Pertanian Bogor, Bogor. 
Sudarmadji, S., B. Haryono, dan Suhardi. 1997.

Prosedur Analisa untuk Bahan Makanan dan

Pertanian. Liberty. Yogyakarta.

Swatland, H.J. 2000. Meat Processing Improving

Quality: On-line Monitoring of Meat

Quality. Woodhead Publishing Limited.

England.

Syaiful, F. 2010. Pengaruh Penambahan Ekstrak Etanol Cengkeh (Eugenia caryophyllata Thunb)

dalam Sosis untuk Penghambatan

Kerusakan Oksidatif Lemak. Skripsi.

Iinstitut Pertanian Bogor.

Tien, R. Muchtadi dan Sugiyono. 1992. Petunjuk Laboratorium Ilmu Pengetahuan Bahan Pangan. Bogor: IPB-Press.

Tisnajaya, D. 2006. Bebas kolesterol dan demam berdarah dengan angkak. Penebar Swadaya, Depok Jakarta

Winarno, F. G. 2002. Kimia Pangan dan Gizi. PT Gramedia Pustaka Utama, Jakarta.

Yuwanta, Tri. 2004. Dasar Ternak Unggas. Kanisius. Yogyakart. 